This document is the Accepted Manuscript version of a Published Work that appeared in final form in Journal of Thermal Analysis and Calorimetry, copyright $@$ Springer after peer review and technical editing by the publisher.

To access the final edited and published work see http://link.springer.com/article/10.1007\%2Fs10973$\underline{016-6038-x}$

\title{
FIBERS AND FIBER COCKTAILS TO IMPROVE FIRE RESISTANCE OF CONCRETE
}

Olivér Czoboly ${ }^{1}$, Éva Lublóy ${ }^{1}$, Viktor Hlavička ${ }^{1}$, György L. Balázs ${ }^{1}$, Orsolya Kéri ${ }^{2}$, Imre Miklós Szilágyi ${ }^{2,3}$

${ }^{1}$ Budapest University of Technology and Economics, Department of Construction Materials and Technologies, H-1111 Budapest, Müegyetem rkp 3.

${ }^{2}$ Department of Inorganic and Analytical Chemistry, Budapest University of Technology and Economics, H-1111 Budapest, Szt. Gellért tér 4. Hungary

${ }^{3}$ Technical Analytical Chemistry Research Group of the Hungarian Academy of Sciences, Budapest University of Technology and Economics, H-1111 Budapest, Szt. Gellért tér 4. Hungary

Corresponding author: Viktor Hlavička, viktor.hlavicka@gmail.com

\begin{abstract}
Our study was directed to improve the residual flexural strength and the heat resistant properties of concrete exposed to high temperatures using different fiber cocktail loadings including steel, polymer or cellulose fibers. At first the morphology and the thermal properties of the fibers and the fiber/cement composites were investigated by SEM and TG/DTA-MS. Then the influence of fiber type and amount on residual flexural strength were tested after cooling back from 150, 500 or $800{ }^{\circ} \mathrm{C}$ temperature loadings. By adding steel, cellulose and polymer (polypropylene) fibers to cement, improvements both in post-cracking residual flexural strength and in insensitivity against explosive spalling were reached.
\end{abstract}

\section{Keywords}

TG/DTA-MS, SEM, fiber, fiber cocktail, concrete, residual flexural strength, spalling 


\section{Introduction}

Due to the large number of fire cases, the design of building structures against fire has become more and more important [1-3], and in fact mandatory with the implementation of Eurocodes in Europe.

In general, the behavior of concrete structures at high temperatures or in fire is more favorable than the behavior of steel or wood structures. At elevated temperatures the strength of concrete decreases due to physical and chemical changes and the deterioration of concrete at such temperatures has two forms: (1) local damage in the material itself and (2) global damage resulting the failure of the structural elements. Damage in concrete material can occur in reinforced concrete structures during fire, which may be due to various causes, i.e. different thermal expansion of the hardened cement paste and the aggregate; internal water vapor pressure; or different temperature in the cross-section as well as along the length of the element [4]. In some cases excessive cracking, decrease of bond and anchorage between the concrete and reinforcement or spalling of concrete cover can also occur during fire [5].

Thielen [6] concluded that changes in strength of concrete subjected to high temperatures depended on the type of cement and aggregate, the w/c ratio, the aggregate-to-cement ratio, the initial moisture content and the way of temperature loading. Other researchers emphasize the importance of the pore system on residual compressive strength [7]. During the cooling process concrete is not able to regain its original characteristics $[8,9]$.

The explosive spalling at elevated temperatures is mainly caused by the water boiling inside the concrete. The generated steam cannot leave the concrete fast enough. Hence, due to steam accumulation, the inside pressure rapidly rises and it destroys the external concrete layers providing then free release way for the accumulated steam [10].

The fragments of the explosive spalling may be dangerous to the escaping people and to the firefighting crew. In addition, the reinforcements situated below the detached concrete layers are prone to heat up significantly faster, causing the premature collapse of the whole structure. The explosive spalling is a typical failure mode of the concrete tunnel elements [1]. In the case of tunnel fires the temperature rise is rapid, therefore the water evaporation is also intensive. However, explosive spalling may also occur in building fires [3].

Different fiber types may improve different properties of concrete. Steel fibers in concrete significantly influence the hardened properties [11], i.e. they increase the post-crack tensile strength, the shear strength, the impact resistance, the fatigue resistance and reduce the crack widths. In contrast, the fire resistance of concrete structures is generally considered not to be 
influenced by steel fibers, though they may reduce the degree of spalling by bridging areas of spalled concrete [11]. Spalling of concrete in a fire may be reduced by the addition of an adequate dosage of micro polymer fibers (diameter from 3 to $32 \mu \mathrm{m}$ with typical dosage of 1$2 \mathrm{~kg} \mathrm{~m}^{-3}$ ) [11-15]. The terminology fiber cocktail is used if several types of fibers or several geometries of the same type of fiber are simultaneously used.

Hence, our aim was to improve the residual flexural strength and the properties of concrete exposed to high temperatures using different fiber cocktails including steel, polymer and cellulose fibers. At first the morphology and the thermal properties of the fibers and the fiber/cement composites were investigated by SEM and TG/DTA-MS. Then the specimens were annealed at selected temperatures $\left(150,500\right.$ or $\left.800{ }^{\circ} \mathrm{C}\right)$ for $1 \mathrm{~h}$, and after cooling down the influence of type and amount of fibers on residual flexural strength in cold state were tested by three-point bending tests.

\section{Experimental}

\subsection{Sample preparation}

Our concrete compositions are presented in Table 1.

The consistency was kept to be constant by using admixture (flow class: F4). The mixing process was carried out by pan type concrete mixer (with activator). The composition of cement are presented in Table 2. We tested concretes reinforced with short steel fibers, micro polymer fibers or cellulose fibers together (fiber cocktail) or alone (Table 3). 
Table 1: Concrete compositions

\begin{tabular}{|l|l|c|}
\hline \multicolumn{1}{|c|}{ Material } & \multicolumn{1}{|c|}{ Type } & $\begin{array}{c}\text { Mass in concrete / } \\
\mathrm{kg} \text { per } 1 \mathrm{~m}^{3} \text { concrete }\end{array}$ \\
\hline \multirow{2}{*}{ Aggregate } & $0 / 4 \mathrm{~mm}$ fraction $(45 \%)$ & 824 \\
\cline { 2 - 4 } & $4 / 8 \mathrm{~mm}$ fraction $(55 \%)$ & 1008 \\
\hline \multirow{2}{*}{ Fement } & CEM I $42.5 \mathrm{~N}$ & 380 \\
\hline \multirow{2}{*}{ Fiber } & steel fiber $(1.0 \mathrm{~V} \%)$ & 78.50 \\
\cline { 2 - 4 } & micro polymer (polypropylene) fiber $(0.1$ or $0.2 \mathrm{~V} \%)$ & 0.91 or 1.82 \\
\cline { 2 - 4 } & cellulose fiber $(0.1$ or $0.2 \mathrm{~V} \%)$ & 1.50 or 3.00 \\
\hline Water & $\mathrm{m}_{\mathrm{w}} / \mathrm{m}_{\mathrm{c}}=0.43$ & 163 \\
\hline Admixture & Glenium C300 (max. $\left.0.7 \mathrm{~m}_{\mathrm{c}} \%\right)$ & max 2.66 \\
\hline
\end{tabular}

Table 2: Compositions of cement

\begin{tabular}{|c|c|c|c|c|c|c|c|c|c|c|}
\hline \multicolumn{10}{|c|}{ Chemical composition / \% } \\
\hline $\mathrm{SiO}_{2}$ & $\mathrm{Al}_{2} \mathrm{O}_{3}$ & $\mathrm{Fe}_{2} \mathrm{O}_{3}$ & $\mathrm{CaO}$ & $\mathrm{MgO}$ & $\mathrm{TiO}_{2}$ & $\mathrm{MnO}$ & $\mathrm{Na}_{2} \mathrm{O}$ & $\mathrm{K}_{2} \mathrm{O}$ & $\mathrm{SO}_{3}$ & $\mathrm{Cl}$ \\
\hline 18,99 & 4,48 & 3,04 & 61,87 & 1,39 & 0,24 & 0,28 & 0,08 & 0,46 & 2,89 & 0,038 \\
\hline
\end{tabular}

Table 3: Properties of tested fibers

\begin{tabular}{|c|l|c|c|c|c|c|}
\hline Sign & \multicolumn{1}{|c|}{ Material } & $\begin{array}{r}\text { Fiber } \\
\text { length } \\
/ \mathrm{mm}\end{array}$ & $\begin{array}{c}\text { Fiber } \\
\text { equivalent } \\
\text { diameter/ } \mu \mathrm{m}\end{array}$ & $\begin{array}{c}\text { Density } \\
/ \\
\mathrm{kg} \mathrm{m}^{-3}\end{array}$ & $\begin{array}{c}\text { Tensile } \\
\text { strength/ } \\
\mathrm{N} \mathrm{mm}^{-2}\end{array}$ & $\begin{array}{c}\text { Ignition } \\
\text { temperature/ } \\
{ }^{\circ} \mathrm{C}\end{array}$ \\
\hline $\mathrm{S}$ & Steel (brass-coated) & 13 & 200 & 7850 & 3000 & \\
\hline $\mathrm{P}$ & $\begin{array}{l}\text { Micro polymer } \\
\text { (polypropylene) }\end{array}$ & 12 & 20 & 910 & $400-500$ & 400 \\
\hline $\mathrm{Ce}$ & Cellulose & 12 & 12 & 1500 & & 460 \\
\hline
\end{tabular}

The tested fiber cocktails and amount of fibers are presented in Table 4. After removing from the formwork, the specimens were stored in water for 7 days then kept at ambient conditions until testing. The samples were 28 days old at the time of the tests. During annealing, the specimens were kept for one hour at the selected temperature $\left(150,500\right.$ or $\left.800{ }^{\circ} \mathrm{C}\right)$. They were then cooled down in laboratory conditions, and tested at room temperature. 
Table 4: The tested fiber cocktails and amount of fibers [V\%]

\begin{tabular}{|l|c|c|c|c|c|c|c|c|}
\hline Mix & Mix & Mix & Mix & Mix & Mix & Mix & Mix & Mix \\
1 & 2 & 3 & 4 & 5 & 6 & 7 & 8 \\
\hline Steel (S) & - & - & - & 1.0 & 1.0 & 1.0 & 1.0 & 1.0 \\
\hline Polymer (P) & - & 0.1 & - & - & 0.1 & 0.2 & - & - \\
\hline Cellulose (Ce) & - & - & 0.1 & - & - & - & 0.1 & 0.2 \\
\hline
\end{tabular}

\subsection{Measurements}

TG/DTA measurements of the concrete and fibers were carried out on an STD 2960 Simultaneous DTA/TGA (TA Instruments Inc.) thermal analyzer using a heating rate of $10{ }^{\circ} \mathrm{C}$ $\min ^{-1}$ and Pt pans. The thermobalance was purged with air $\left(130 \mathrm{~mL} \mathrm{~min}^{-1}\right)$. Evolved gases were measured by a Thermostar GSD 200 (Balzers Instruments) quadrupole mass spectrometer (MS). A heated $\left(200{ }^{\circ} \mathrm{C}\right) 100 \%$ methyl deactivated fused silica capillary provided the on-line coupling. The selected ions between $\mathrm{m} / \mathrm{z}=4-184$ were monitored through 64 channels in Multiple Ion Detection Mode (MID) with a measuring time of $0.5 \mathrm{~s} \mathrm{channel}^{-1}$.

To check the morphology, SEM images were obtained by a JEOL JSM-5500LV scanning electron microscope.

The three-point bending tests were carried out on 3 parallel specimens with $70 \times 70 \times 250 \mathrm{~mm}$ dimensions by each mixture after annealing at selected temperatures $\left(150,500\right.$ or $\left.800{ }^{\circ} \mathrm{C}\right)$ with $1 \mathrm{~mm} / \mathrm{min}$ loading rate.

\section{Results and discussion}

\subsection{TG/DTA-MS}




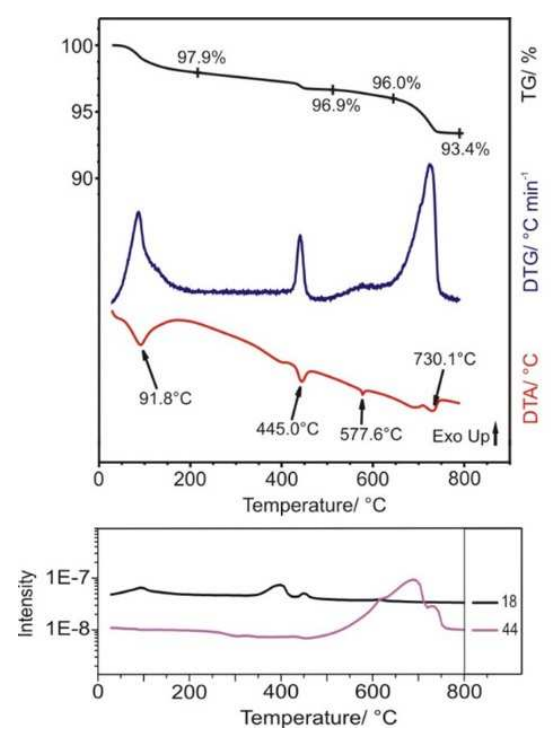

Figure 1: Thermal decomposition of bare concrete (Mix 1)

Table 5: TG/DTA-MS evolved gas ions '[16-19]

\begin{tabular}{|c|c|}
\hline $\mathrm{m} / \mathrm{z}$ & Fragment \\
\hline 18 & $\mathrm{H}_{2} \mathrm{O}^{+}$ \\
\hline 41 & $\mathrm{C}_{3} \mathrm{H}_{5}{ }^{+}$ \\
\hline 44 & $\mathrm{CO}_{2}^{+}$ \\
\hline 55 & $\mathrm{C}_{4} \mathrm{H}_{7}^{+}$ \\
\hline 57 & $\mathrm{C}_{4} \mathrm{H}_{9}{ }^{+} /$levoglucosan fragment ${ }^{+}$ \\
\hline 60 & acetic acid $^{+} /$hydroxyacetaldehyde ${ }^{+}$ \\
\hline 69 & $\mathrm{C}_{5} \mathrm{H}_{9}{ }^{+}$ \\
\hline 74 & 1-hydroxy-2-propanone ${ }^{+}$ \\
\hline 82 & 2-methylfuran ${ }^{+}$ \\
\hline 83 & $\mathrm{C}_{6} \mathrm{H}_{11}{ }^{+}$ \\
\hline 96 & furfural $^{+}$ \\
\hline 97 & $\mathrm{C}_{7} \mathrm{H}_{13}{ }^{+}$ \\
\hline 98 & furfuryl alcohol ${ }^{+}$ \\
\hline 111 & $\mathrm{C}_{8} \mathrm{H}_{15}{ }^{+}$ \\
\hline 114 & 3-hydroxy-2-penteno-1,5-lactone ${ }^{+}$ \\
\hline 125 & $\mathrm{C}_{9} \mathrm{H}_{17}{ }^{+}$ \\
\hline 126 & 5-hydroxymethyl-2-furfural ${ }^{+}$ \\
\hline 139 & $\mathrm{C}_{10} \mathrm{H}_{19}{ }^{+}$ \\
\hline 162 & $\operatorname{levoglucosan}^{+}$ \\
\hline
\end{tabular}


In case of the bare concrete that contained no fibers (Fig. 1) the mass loss occurred in four steps, all of which were accompanied by an endothermic heat effect. In the first step between 50 and $150{ }^{\circ} \mathrm{C}$ the concrete sample lost its physically bound water content, and water from the decomposition of ettringite and the calcium silicate hydrates were also released here. Then between 420 and $460{ }^{\circ} \mathrm{C}$ took place the dehydration of $\mathrm{Ca}(\mathrm{OH})_{2}$. In the third and fourth overlapping steps between 480 and $750{ }^{\circ} \mathrm{C}$ with continuous evolution of $\mathrm{CO}_{2}$ the $\mathrm{CaCO}_{3}$ decomposition occurred $[20,21]$.

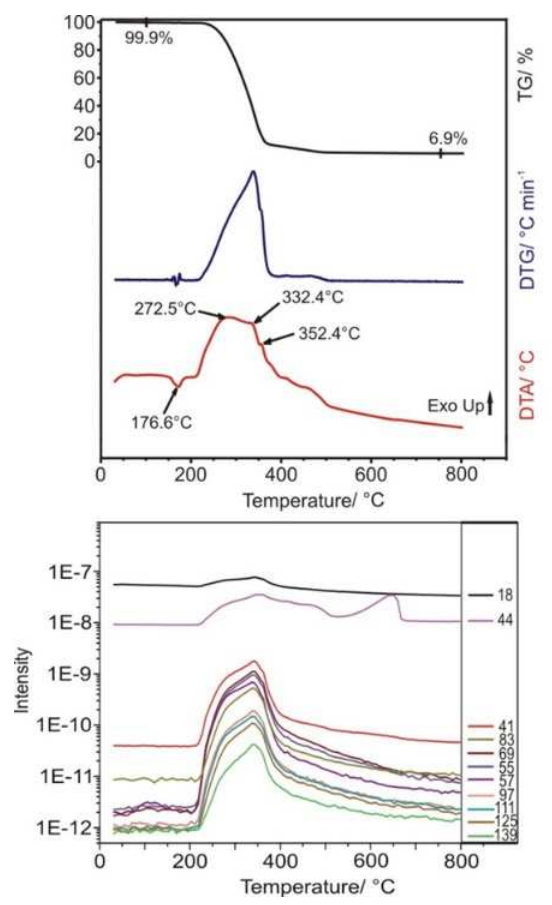

Figure 2: Decomposition of polypropylene fibers

The decomposition of the polypropylene fibers happened in one step (Fig. 2). At first the polymer melted (endothermic DTA peak at $177{ }^{\circ} \mathrm{C}$ ), then between 230 and $500{ }^{\circ} \mathrm{C}$ the sample decomposed and burnt in overlapping reaction accompanied with the release of $\mathrm{H}_{2} \mathrm{O}, \mathrm{CO}_{2}$ and several other fragments in a wide mass range (see the ion current curves in Fig. 2 and their assignment in Table 5) [22, 23]. The decomposition of PP was endothermic, while the combustion was exothermic; and the net DTA peak was exothermic. The $\mathrm{CO}_{2}$ evolving between 550 and $680{ }^{\circ} \mathrm{C}$ is coming from the capillary connecting the thermal analyzer to the mass spectrometer. 


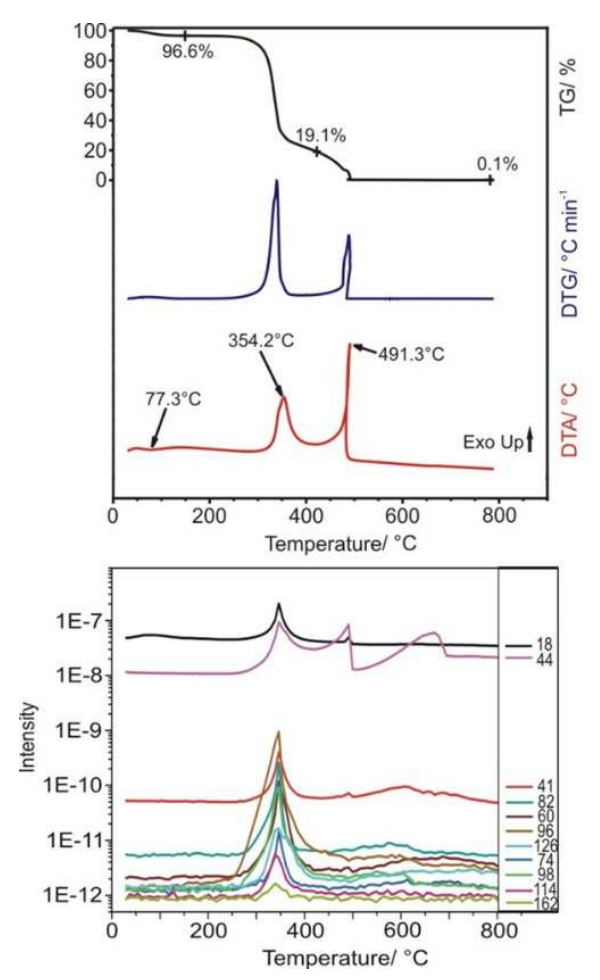

Figure 3: Decomposition of cellulose fibers

Similar to the concrete sample, in the first step the cellulose (Fig. 3) lost its physically bound water content. After that the mass loss happened in two stages. Between 250 and $400{ }^{\circ} \mathrm{C}$ the structure of cellulose was decomposed, accompanied by the evolution of several volatile species (Table 5). In the next step between 450 and $500{ }^{\circ} \mathrm{C}$ the residual char was burnt and only $\mathrm{CO}_{2}$ evolved [24]. Here due to the oxidation in air, the DTA peaks were endothermic again. The $\mathrm{CO}_{2}$ released from $550{ }^{\circ} \mathrm{C}$ is coming from the capillary.

As expected, the steel fibers did not decompose until $800^{\circ} \mathrm{C}$, thus there thermoanalytical curves are not presented.

The amount of fibers, especially the quantity of cellulose and polypropylene fibers, was very low in the concrete samples, and hence they did not influence the thermal behavior of concrete in a detectable way. Thus, the TG/DTA-MS curves of the composite samples are also not presented here.

From the thermoanalytical results of the bare concrete, polypropylene and cellulose, it can be concluded that they all lost their adsorbed water content until $150{ }^{\circ} \mathrm{C}$. The decomposition cellulose and the polymer was finished until $500{ }^{\circ} \mathrm{C}$, while concrete decomposed until $800{ }^{\circ} \mathrm{C}$. Bases on these, for the Mix 1-8 samples annealing temperatures of 150,500 and $800{ }^{\circ} \mathrm{C}$ were selected. 


\subsection{SEM measurements}

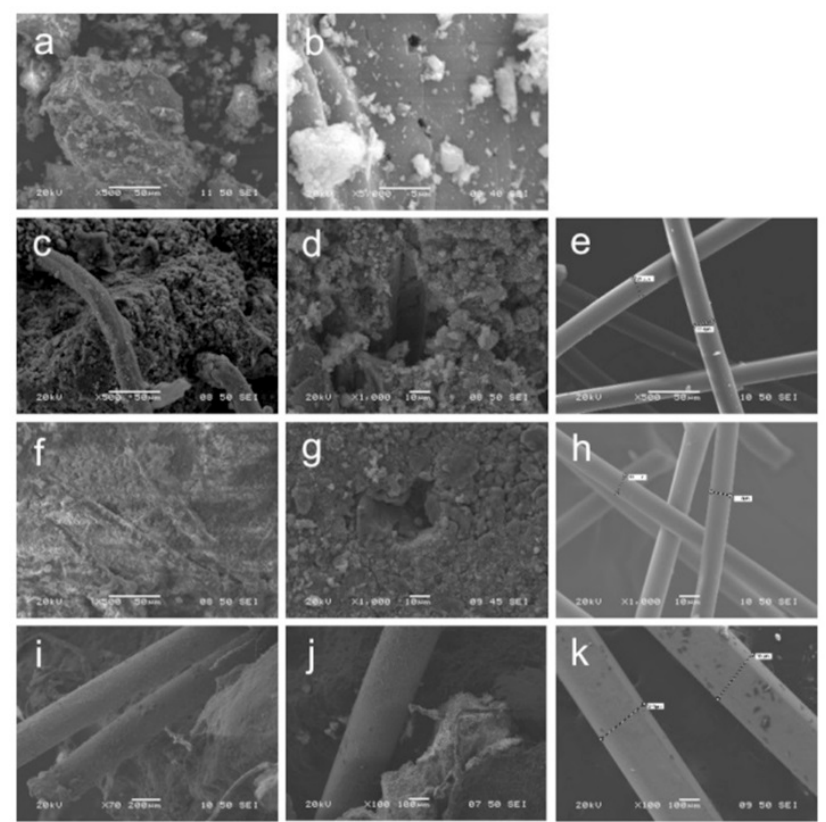

Figure 4: SEM images of the samples a) Mix1, b) Mix1 after annealing at $800{ }^{\circ} \mathrm{C}$, c) Mix2, d) Mix 2 after annealing at $800{ }^{\circ} \mathrm{C}$, e) bare polypropylene fibers, f) Mix3, g) Mix3 after annealing at $800{ }^{\circ} \mathrm{C}, \mathrm{h}$ ) bare cellulose fibers, i) Mix 4, j) Mix 4 after annealing at $800{ }^{\circ} \mathrm{C}, \mathrm{k}$ ) bare steel fibers

In Fig. 4 SEM images of Mix1, Mix2, Mix3 and Mix4 before and after heating them to $800{ }^{\circ} \mathrm{C}$ are shown, and also the morphology of the bare fibers. Before heating the embedded fibers can be clearly seen in the mixtures. After heating few micrometer wide holes and cracks appeared on the surface of all samples caused by the volatile decomposition products of concrete. In the case of Mix2 and Mix3, the polymer and cellulose fibers were burnt out, and due to this wider holes were also present after the heat treatment, pointing to the original places of these fibers in concrete. There was no change observed upon annealing in the state of the steel fibers.

\subsection{Flexural behavior with different type of fiber and temperature loadings}

The results in Fig. 5 indicate that the addition of either micro polymer (Mix2) or cellulose fibers (Mix3) (without steel fibers) to concrete do not significantly influence the post-cracking residual flexural strength both before and after 150,500 or $800{ }^{\circ} \mathrm{C}$ temperature loadings. In Fig. 6 the flexural stress vs. displacement diagrams are presented for fiber reinforced concrete samples with steel fibers $(1.0 \mathrm{~V} \%)$ (Mix4), with both steel $(1.0 \mathrm{~V} \%)$ and micro 
polymer fibers $(0.1 \mathrm{~V} \%$ or $0.2 \mathrm{~V} \%)$ (Mix5-6), or with both steel $(1.0 \mathrm{~V} \%)$ and cellulose fibers $(0.1 \mathrm{~V} \%$ or $0.2 \mathrm{~V} \%)$ (Mix 7-8) both before and after annealing at 150,500 or $800{ }^{\circ} \mathrm{C}$.

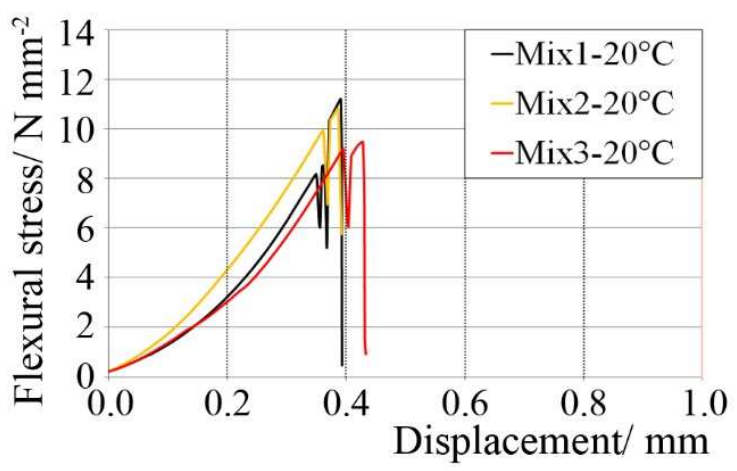

a)

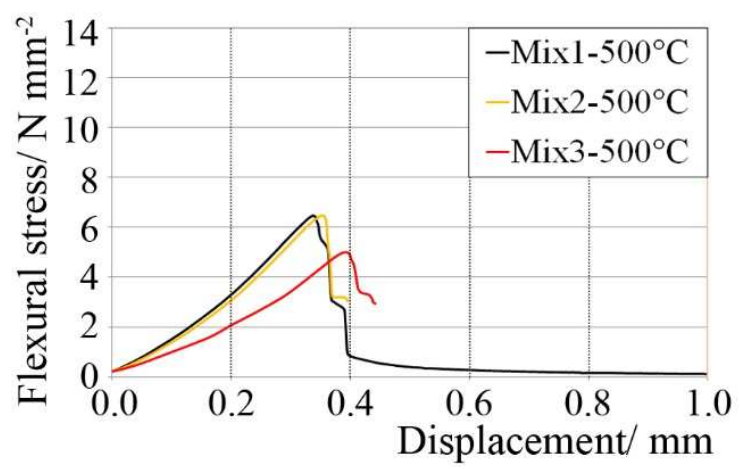

c)

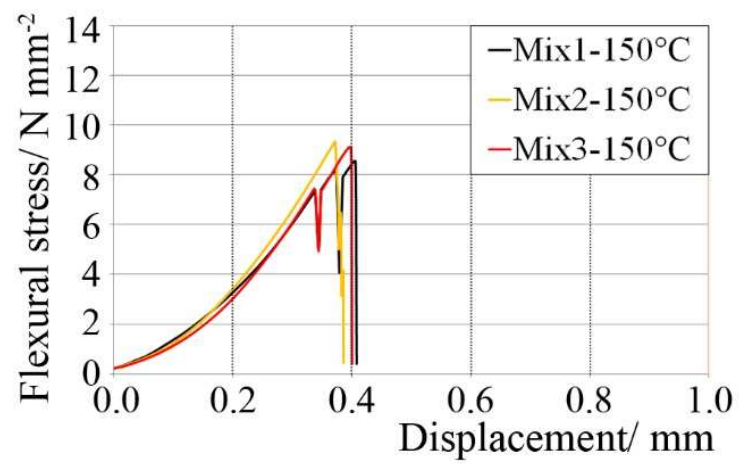

b)

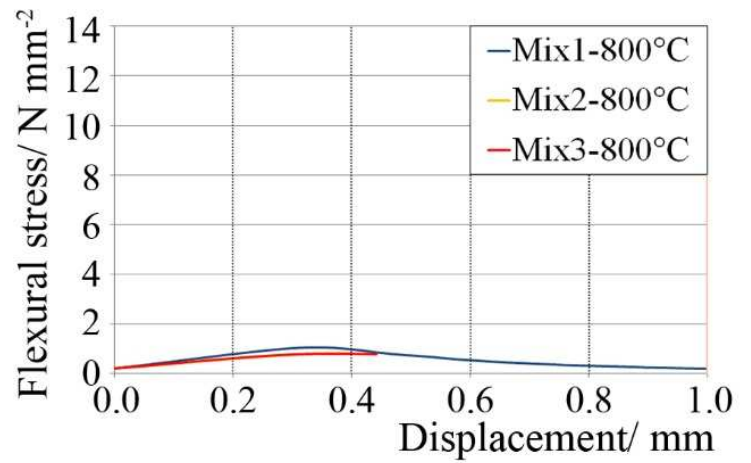

d)

Figure 5: Flexural stress-displacement curves of three-point bending tests of concrete beams without or with micro polymer or cellulose fibers $(0.1 \mathrm{~V} \%)$,
a) without temperature loading $\left(20^{\circ} \mathrm{C}\right)$,
b) after $150{ }^{\circ} \mathrm{C}$ temperature loading,
c) after $500{ }^{\circ} \mathrm{C}$ temperature loading,
d) after $800{ }^{\circ} \mathrm{C}$ temperature loading. 


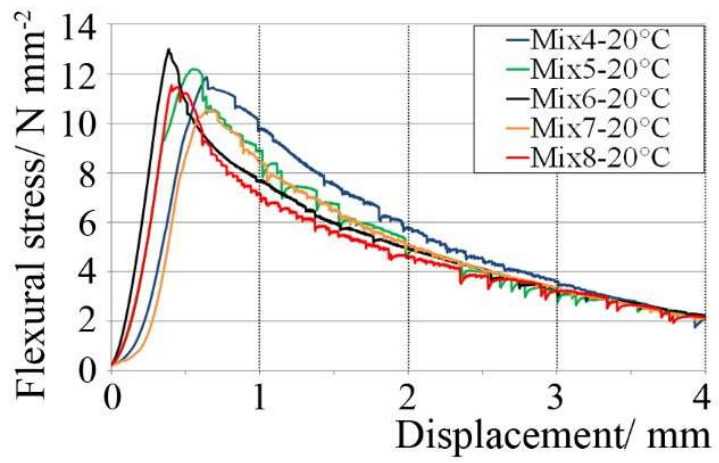

a)

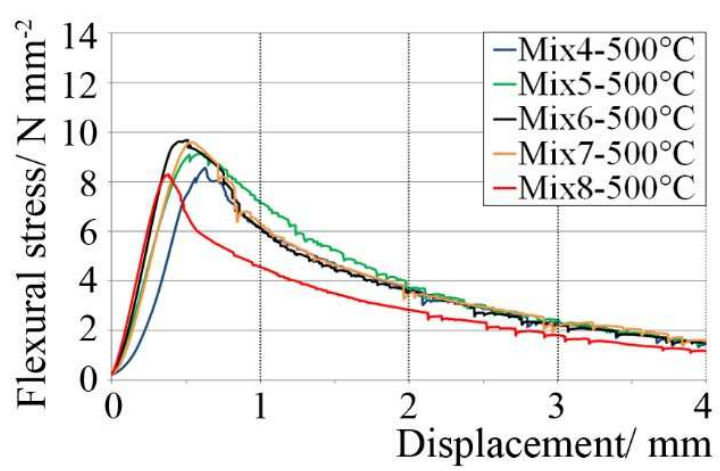

c)

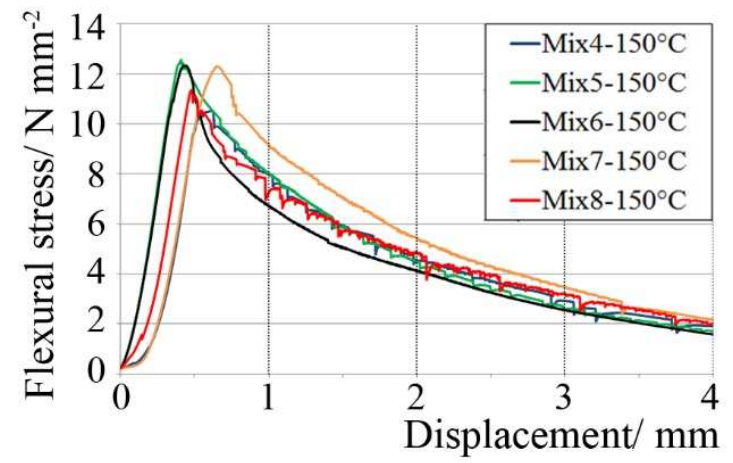

b)

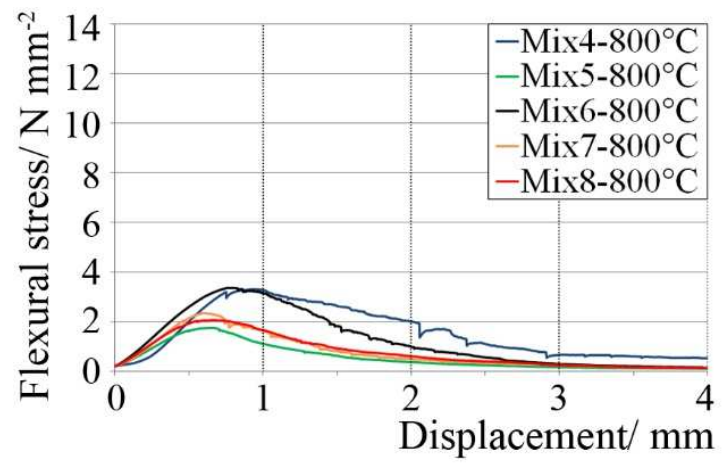

d)

Figure 6: Flexural stress-displacement curves of three-point bending tests of FRC beams with steel fibers $(1.0 \mathrm{~V} \%)$ and micro polymer or cellulose fibers $(0.1 \mathrm{~V} \%$ or $0.2 \mathrm{~V} \%)$,

a) without temperature loading $\left(20^{\circ} \mathrm{C}\right)$,

c) after $500{ }^{\circ} \mathrm{C}$ temperature loading, b) after $150{ }^{\circ} \mathrm{C}$ temperature loading,

d) after $800{ }^{\circ} \mathrm{C}$ temperature loading.

The test results in Figs. 5 and 6 reveal that the steel fibers have the most remarkable influence $(1.0 \mathrm{~V} \%)$ on the post-cracking flexural stress at each studied temperature. When only steel fibers were added to concrete, the post-cracking flexural stress increased considerably. However, no considerable differences were observed for specimens including either micro polymer or cellulose fibers besides steel fibers. This shows that polymer and cellulose fibers do not have a beneficial impact on the post-cracking flexural stress.

The results of flexural stress-displacement curves of three-point bending tests (Figs. 5-6) also show that there was a considerable reduction of both flexural strength and residual flexural strength in the temperature range of 500 and $800{ }^{\circ} \mathrm{C}$, which can be mainly explained by the chemical changes of concrete in this temperature region [25-27]. Possible reasons can be reactions in the cement stone such as dehydration of $\mathrm{Ca}(\mathrm{OH})_{2}$ below $500{ }^{\circ} \mathrm{C}$, and decomposition of CSH (calcium-silicate-hydrates) and $\mathrm{CaCO}_{3}$ between 500 and $800{ }^{\circ} \mathrm{C}$. After the temperature 
loading we could observe that the color of the specimens had changed (Fig.7), which was related to the the chemical changes of concrete [28-31].

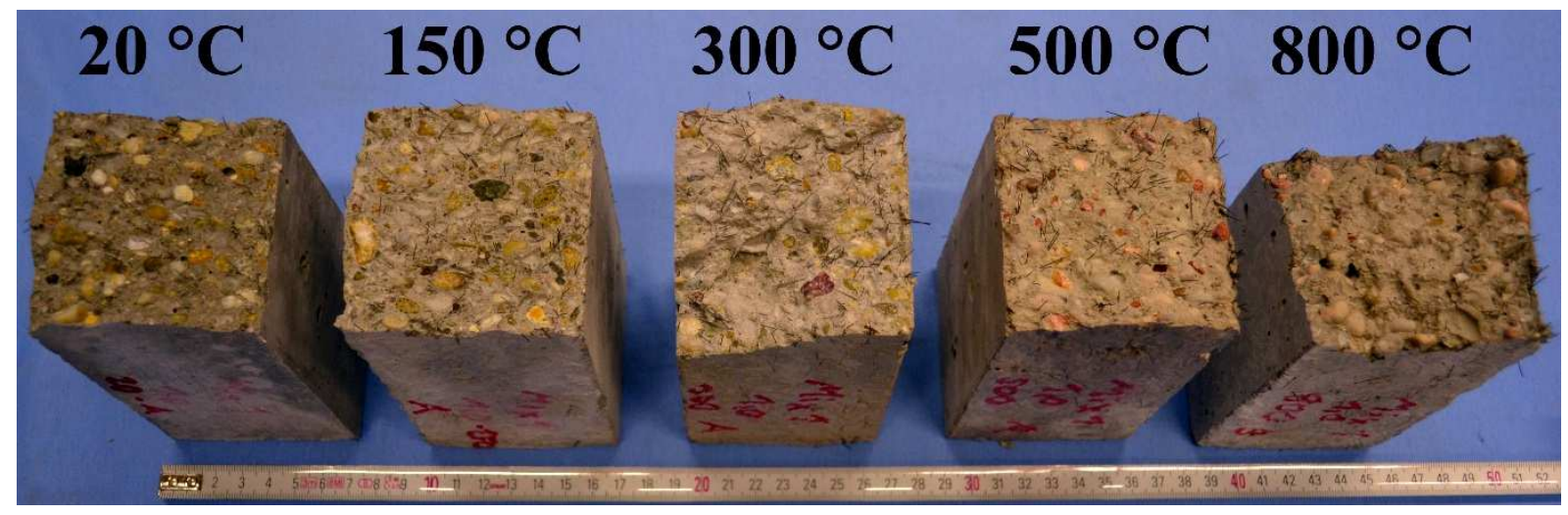

Figure 7: Color of FRC specimens without or with temperature loading (150-800 $\left.{ }^{\circ} \mathrm{C}\right)$ at cold state

In addition to the chemical changes of concrete, modifications of steel properties can also contribute to the reduction of residual flexural strength of FRC. It was observed that there were pulled out steel fibers in the failed cross-section of the flexural test specimens already without temperature loading or after $150-500{ }^{\circ} \mathrm{C}$ annealing (Fig. 8.a). Furthermore, after $800{ }^{\circ} \mathrm{C}$ temperature loading steel fibers were even broken in the failed cross-section (Fig. 8.b). Fig. 9 presents photos obtained with optical microscope of steel fibers taken out from the SFRC specimens after the bending test without or with the various temperature loadings. It is obvious that the mechanical properties of steel fibers deteriorated, as the annealing temperature increased. 


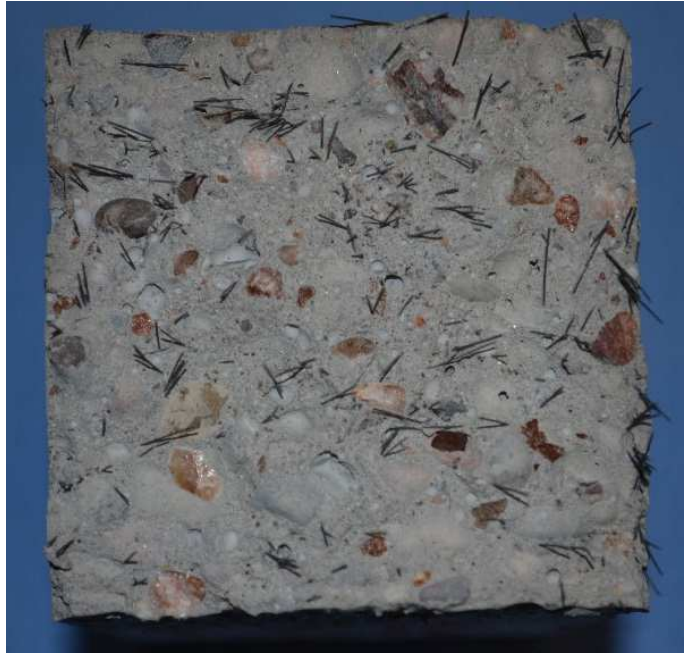

a)

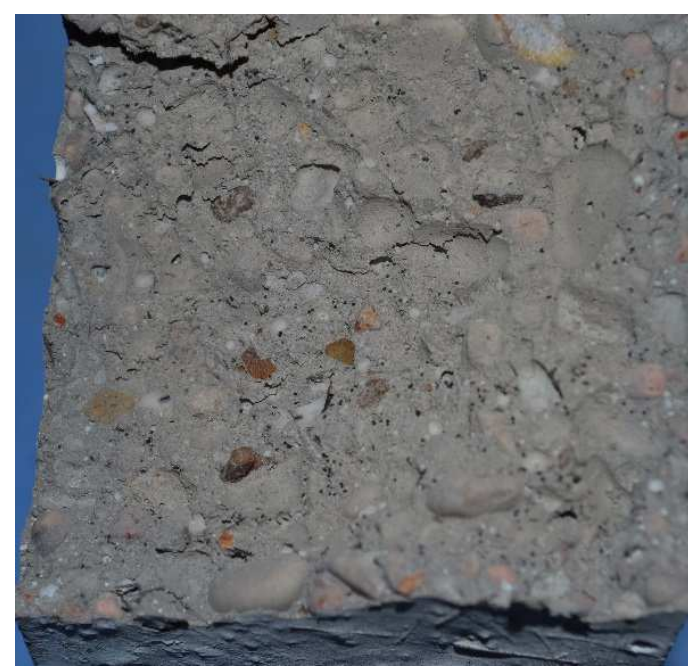

b)

Figure 8: SFRC specimens after temperature loading (fiber content: 1.0 V\%): a) cross-section of specimen failed in flexure, annealing temperature: $500{ }^{\circ} \mathrm{C}$; b) cross-section of specimen failed in flexure, annealing temperature: $800{ }^{\circ} \mathrm{C}$

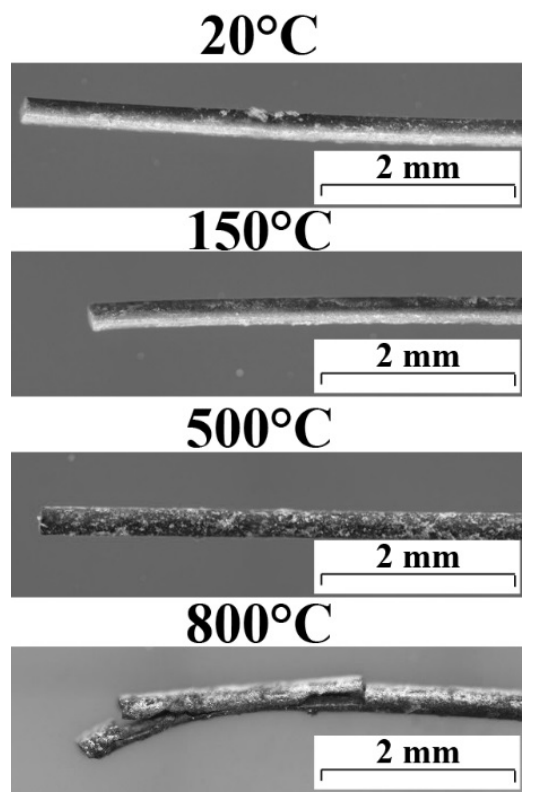

Figure 9: Steel fibers taken from the FRC specimens after the bending test without or with various temperature loadings

\subsection{Spalling behavior with different type of fiber and temperature loading}

Finally, influence of hybrid fibers (steel/polymer/cellulose) on explosive spalling behavior are discussed. When the samples were heated up to the maximal temperature of $800{ }^{\circ} \mathrm{C}$, the explosive spalling was avoided when either polymer fibers $(0.1 \mathrm{~V} \%)$ or cellulose fibers 
$(0.1 \mathrm{~V} \%)$ were used. Similarly, explosive spalling was avoided when fiber cocktails with steel fibers $(1.0 \mathrm{~V} \%)$ and polymer fibers $(0.1$ or $0.2 \mathrm{~V} \%)$, as well as with steel fibers $(1.0 \mathrm{~V} \%)$ and cellulose fibers ( 0.1 or $0.2 \mathrm{~V} \%$ ) were used. In contrast, the explosive spalling was not avoided when only the relatively high amount of steel fibers $(1.0 \mathrm{~V} \%)$ were added to concrete, without the presence of cellulose or polymer fibers (Fig. 10). The beneficial effect of cellulose and polymer fibers is considered to be that, when they are decomposed and combusted below 500 ${ }^{\circ} \mathrm{C}$, empty channel will form in their places all along concrete, as shown previously by SEM results. Then when concrete is annealed at $800{ }^{\circ} \mathrm{C}$, the as-released decomposition product gases can reach the surface using these channels, and their overpressure will not damage considerably the structure of concrete.

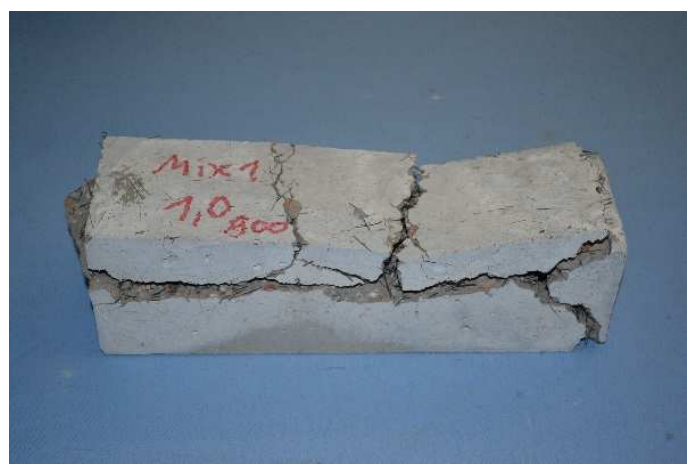

a)

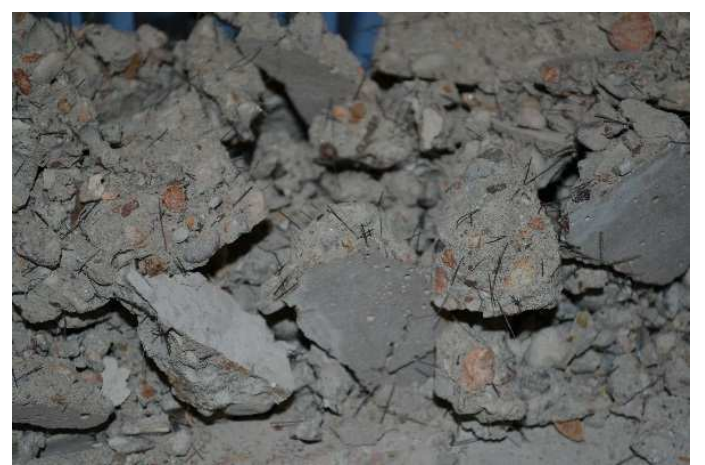

b)

Figure 10: Explosive spalling of SFRC beam with 1.0 V\% short steel fibers after annealing at $800{ }^{\circ} \mathrm{C}$

\section{Conclusions}

Our experimental study was intended to improve concrete properties exposed to high temperatures using different fiber cocktails including steel, micro polymer or cellulose fibers. At first, the morphology of the fibers were studied by SEM, confirming their micrometer scale diameters. TG/DTA-MS investigations of concrete as well as of cellulose and polypropylene fibers showed that they lost their adsorbed water content until $150{ }^{\circ} \mathrm{C}$. While The cellulose and the polymer fibers decomposed completely until $500{ }^{\circ} \mathrm{C}$, while the decomposition of concrete was finished until $800{ }^{\circ} \mathrm{C}$. Hence, we chose 150,500 and $800{ }^{\circ} \mathrm{C}$ as annealing temperature for the concrete and fiber reinforced concrete samples.

Based on the three-point bending tests the short steel fibers $(1.0 \mathrm{~V} \%)$, on the one hand, increased the post-cracking residual flexural strength both with or without temperature loading. On the 
other hand, our experimental results indicated explosive spalling failure upon heating up to $800{ }^{\circ} \mathrm{C}$.

In contrast to steel fibers, cellulose $(0.1$ or $0.2 \mathrm{~V} \%)$ and micro polymer $(0.1$ or $0.2 \mathrm{~V} \%)$ fibers were found to be similarly effective in avoiding explosive spalling when a temperature loading of $800{ }^{\circ} \mathrm{C}$ was applied.

In the case of applying fiber cocktails of short steel fibers together with cellulose fibers or micro polymer fibers improvements were reached both in post-cracking residual flexural strength as well as insensitivity against explosive spalling.

\section{References}

1. Allison R. Inquiry into the Fire on Heavy Goods Vehicle Shuttle 7539 on 18 November 1996. HMSO. London; 1997.

2. Fellinger J, Breunese A. Fire Safe Design: Make it Concrete!. In: Gambarova PG, Felicetti R, Meda A, Riva P, editors. Fire Design of Concrete Structures: What now? What next?, Proceedings of Workshop, Brescia: Starrylink Editrice Brescia, 2015. pp. 313-316.

3. Lublóy É, Czoboly O, Hlavička V, Oros Zs, Balázs GL. Experiences of the fire case of athletic hall of the University of Physical Education in Budapest 15 Oct. 2015, VASBETONÉPÍTÉS. 2015;3:50-55.

4. Lublóy É, Kopecskó K, Balázs GL, et al. J Therm Anal Calorim. 2016; doi:10.1007/s10973-016-5392-Z

5. Balázs GL, Lublóy É. Fire resistance for thin-webbed concrete and masonry elements. Applications of Structural Fire Engineering: Proceedings of the International Conference in Dubrovnik. 2015. pp. 1-6.

6. Thielen KCh. Strength and Deformation of Concrete Subjected to high Temperature and Biaxial Stress-Test and Modelling. Deutscher Ausschuss für Stahlbeton. Book 437. Berlin; 1994.

7. Noumowe A. Mechanical properties and microstructure of high strength concrete containing polypropylene fibres exposed to temperatures up to $200^{\circ} \mathrm{C}$. Cement and Concrete Research. 2005;35:2192-2198

8. Chan SYN, Luo X, Sun W. Effect of high temperature and cooling regimes on the compressive strength and pore properties of high performance concrete. Construction and Building Materials. 2000;14:261-266 
9. Chan YN, Luo X, Sun W. Compressive strength and pore structure of high-performance concrete after exposure to high temperature up to $800^{\circ} \mathrm{C}$. Cement and Concrete Research. 2000;30:247-251.

10. Peng GF, Yang WW, Zhao J, Liu YF, Bian SH, Zhao LH. Explosive spalling and residual mechanical properties of fiber-toughened high-performance concrete subjected to high temperatures. Cement and Concrete Research. 2006;36:723-727.

11. Aßbrock O, Carlswärd J, Dietze R, Guirguis P, Hemrich W, Lambrechts A, Löfgren I, Schulz M, Troy J, Gibbs J, Harrison T, Ressler C. Guidance to fibre concrete. Properties Specification and Practice in Europe. European Ready Mixed Concrete Organization. 2012. pp. 1-39.

12. Rossino C, Monte FLo, Cangiano S, Felicetti R, Gambarova PG. Concrete spalling sensitivity versus microstructure: Preliminary results on the effect of polypropylene fibers. MATEC Web of Conferences. 2013;6:1-9.

13. Rossino C, Monte FLo, Cangiano S, Felicetti R, Gambarova PG. HPC Subjected to High Temperature: A Study on Intrinsic and Mechanical Damage. Key Engineering Materials. 2014;629-630:239-244.

14. Lublóy É. Effect of fire to the concrete structures. PhD dissertation. Budapest. 2008.

15. fib bulletin 46. Fire design of concrete structures - structural behaviour and assessment. State-of-art report. TG 4.3, DCC Document Competence Center Siegmar Kästl e.K. Germany. 2008.

16. Luda MP, Dall' Anese R. On the microstructure of polypropylenes by pyrolysis GC-MS. Polymer Degradation and Stability. 2014;110:35-43.

17. Endo K, Kobayashi N, Aida M, Hoshi T. Spectral Analysis of Polystyrene. Polypropylene, and Poly(methyl methacrylate) Polymers in TOF SIMS and XPS by MO Calculations Using the Model Oligomers. Polymer Journal. 1996;28:901-910.

18. Evans RJ, Milne TA, Soltys MN. Mass spectrometric behaviour of levoglucosan under different ionization conditions and implicatioans for studies of cellulose pyrolysis. Journal of Analytical and Applied Pyrolysis. 1984;6:273-283.

19. Evans RJ, Milne TA. Molecular Characterization of the Pyrolysis of Biomass. 1. Fundamentals. Energy\&Fuels. Vol. 1. No. 2. 1987.

20. Trník A, Sheinherrová L, Medved I, Černý R. Simultaneous DSC and TG analysis of high-performance concrete containing natural zeolite as a supplementary cementitious material. Journal of Thermal Analysis and Calorimetry. 2015;121:67-73. 
21. Narattha C, Thongsanitgarn P, Chaipanich A. Thermogravimetry analysis, compressive strength and thermal conductivity tests of non-autoclaved aerated Portland cement-fly ash-silica fume concrete. Journal of Thermal Analysis and Calorimetry. 2015;122:1120.

22. Sun L, Wu Q, Xie Y, Song K, Lee S, Wang Q, Thermal decomposition of fire-retarded wood flour/polypropylene composites. Journal of Thermal Analysis and Calorimetry. 2016;123:309-318

23. Kannan M, Bhagawan SS, Thomas S, Joseph K. Thermogravimetric analysis and differential scanning calorimetric studies on nanoclay-filled TPU/PP blends. Journal of Thermal Analysis and Calorimetry. 2013;112:1231-1244.

24. Shen D, Ye J, Xiao R, Zhang H. TG-MS analysis for thermal decomposition of cellulose under different atmospheres. Carbohydrate Polymers. 2013;98:514-521.

25. Saad M, Abo-El-Enein SA, Hanna GB, Kotkata MF. Effect of silica fume on the phase composition and microstructure of thermally treated concrete. Cement and Concrete Research. 1996;26:1479-1484.

26. Alqassim MA, Jones MR, Berlouis LEA, Nic Daeid N. A thermoanalytical, X-ray diffraction and petrographic approach to the forensic assessment of fire affected concrete in the United Arab Emirates. Forensic Science International. 2016;264:82-88.

27. Xiong MX, Liew JYR. Mechanical behaviour of ultra-high strength concrete at elevated temperatures and fire resistance of ultra-high strength concrete filled steel tubes. http://dx.doi.org/10.1016/j.matdes.2016.05.050. Materials and Design. 2016;104:414427.

28. Balázs LGy, Lublóy É, Czoboly O. Possible observations on concrete after high tempereture loading. Journal of Faculity of Civil Engineering. ISSN: 0352-6852. 2014:579-586.

29. Balázs LGy, Lublóy É, Czoboly O. Effectiveness of fibres for structural elements in case of fire. FRC 2014: ACI-fib International Workshop "Fibre-reinforced Concrete: From design to structural applications". ISBN 978-2-88394-119-9. ISSN 1562-3610. 2016:269-278

30. Short NR, Purkiss JA, Guise SE. Assessment of fire damaged concrete using colour image analysis. Construction and Building Materials. 2001;15:9-15.

31. Georgali B, Tsakiridis PE. Microstructure of fire-damaged concrete. A case study. Cement \& Concrete Composites 2005;27:255-259. 